\title{
PENYULUHAN DAN PEMERIKSAAN PENYAKIT KECACINGAN PADA PEMULUNG DI KELURAHAN BANGKALA KECAMATAN MANGGALA KOTA MAKASSAR
}

\author{
Jangga ${ }^{1}$, Saparuddin Latu $^{2 *}$, Haerawati Idris ${ }^{3}$, Nining Ade Ningsih ${ }^{4}$, Rosdiana $^{5}$ \\ 1,2Program Studi Farmasi Universitas Mega Rezky \\ ${ }^{3}$ Program Studi Kesehatan Masyarakat Universitas Sriwijaya \\ ${ }^{4}$ Program Studi Kesehatan Masyarakat STIK Tamalatea Makassar \\ ${ }^{5}$ Program Studi Kesehatan Masyarakat Universitas Mega Buana \\ jangga.angga@yahoo.co.id ${ }^{1}$, saparuddinlatu@gmail.com² \\ niningadeningsih@stiktamalateamks.ac.id ${ }^{4}$, rosdianabunga23@gmail.com ${ }^{5}$
}

Submi tted : 30 September 2021 Accepted : 21 Desember 2021 Published : 31 Desember 2021

\begin{abstract}
Abstrak Penyakit kecacingan masih merupakan masalah kesehatan masyarakat di Indonesia. Nematoda usus adalah sejumlah spesies yang ditularkan melalui tanah yang tercemar oleh cacing. Infeksi cacing menyerang semua golongan umur terutama anak-anak dan balita yang dapat mengganggu tumbuh kembang anak, sedangkan jika infeksi terjadi pada orang dewasa dapat menurunkan produktivitas kerja. Oleh karena itu, kami mengadakan pengabdian masyarakat ini adalah untuk mengetahui ada tidaknya telur nematoda usus pada kuku tangan pemulung sebagai penyebab penyakit kecacingan untuk kemudian melakukan pengobatan; melakukan penyuluhan kepada pemulung mengenai pencegahan dan penularan penyakit kecacingan serta PHBS; dan pemberian obat cacing bagi pemulung di Kelurahan Bangkala Kecamatan Manggala Kota Makassar. Pengambilan sampel kuku tangan pemulung untuk pemeriksaan penyakit kecacingan dan penyuluhan kesehatan serta pembagian obat cacing dilaksanakan pada tanggal 10-11 Agustus 2020. Kegiatan dimulai dengan pemeriksaan nematoda usus pada kuku tangan pemulung dengan metode sedimentasi, menentukan ada tidaknya telur atau larva nematoda usus dalam kuku pemulung yang diperiksa, kemudian penyuluhan mengenai pencegahan dan penularan penyakit kecacingan, PHBS, serta pembagian obat cacing kepada para pemulung. Pemeriksaan penyakit kecacingan dan penyuluhan serta pembagian obat cacing kepada para pemulung di Kelurahan Bangkala Kecamatan Manggala Kota Makassar telah dilaksanakan dengan baik. Berdasarkan hasil pemeriksaan didapatkan pemulung yang telah terinfeksi telur cacing nematoda usus dengan prosentase $8 \%$.
\end{abstract}

Kata Kunci : Penyakit Kecacingan, Penyuluhan, Pemeriksaan 


\section{PENDAHULUAN}

Penyakit kecacingan masih merupakan masalah kesehatan masyarakat di Indonesia. Penyakit kecacingan yang dianggap sebagian manyarakat sebagai penyakit ringan dan mudah diobati ternyata dapat memberikan dampak kesehatan yang kurang menguntungkan bahkan dapat mengancam jiwa penderitanya.

Pemulung adalah seseorang yang memiliki pekerjaan sebagai pencari barang yang sudah tidak terpakai atau orang yang bekerja sebagai pengais sampah, dimana antara pemulung dan sampah sebagai dua sisi mata uang, diaman ada sampah pasti ada pemulung dan dimana ada pemulung disitu ada sampah. Tumpukan sampah menjadi tempat yang nyaman bagi bakteri, kuman dan virus sebuah penyakit untuk berkembang biak dan menyebarkan penyakitnya.

Penyebaran penyakit tersebut selanjutnya dikenal sebagai infeksi yang menyerang manusia (Ruhimat, U., 2014).

Berdasarkan hasil survei dilapangan, para pemulung memungut sampah tidak menggunakan sarung tangan, walaupun menggunakan alat bantu untuk pengungkit sampah. Rumah yang berdekatan dengan tempat pembuangan sampah dan hampir disemua rumah tidak mempunyai jamban atau tempat buang air besar sehingga tidak sedikit penduduk sekitar yang buang air besar didekat tempat pembuangan sampah. Hal ini menyebabkan sampah dapat bercampur dengan tinja manusia. Melihat profesi pemulung yang akrab dengan sampah dan barang- barang bekas, tak jarang mereka yang tak kuat fisiknya terserang penyakit.

Nematoda usus terdapat sejumlah spesies yang ditularkan melalui tanah yang tercemar oleh cacing. Infeksi cacing menyerang semua golongan umur terutama anakanak dan balita maka dapat mengganggu tumbuh kembang anak, sedangkan jika infeksi terjadi pada orang dewasa dapat menurunkan produktivitas kerja (Mardiana, 2008). Pemeriksaan Nematoda usus pada kuku tangan pemulung secara berkala, bermanfaat bagi para pemulung untuk memastikan perlu atau tidaknya pengobatan penyakit kecacingan. Pemulung yang ternyata menderita penyakit kecacingan harus 
segera berobat untuk mencegah dampak negatif akibat penyakit kecacingan tersebut.

Berdasarkan survei awal lapangan atau analisis situasi dan pentingnya diagnosis dini penyakit kecacingan bagi setiap pemulung yang berada di Kelurahan Bangkala Kecamatan Manggala Kota Makassar, maka yang menjadi masalah adalah : Bagaimana status kesehatan para pemulung yang berada di Kelurahan Bangkala Kecamatan Manggala Kota Makassar dari aspek penyakit kecacingan.

Tujuan kegiatan ini adalah untuk mengetahui ada tidaknya telur nematoda usus pada kuku tangan pemulung sebagai penyebab penyakit kecacingan untuk kemudian melakukan pengobatan; melakukan penyuluhan kepada pemulung mengenai pencegahan dan penularan penyakit kecacingan serta PHBS; dan pemberian obat cacing bagi pemulung di Kelurahan Bangkala Kecamatan Manggala Kota Makassar.

\section{Manfaat}

kegiatan

pemeriksaan Nematoda usus pada kuku tangan pemulung secara berkala, maka penyakit kecacingan dapat dideteksi lebih dini. Pemulung yang ternyata menderita penyakit kecacingan, harus segera berobat ke sarana kesehatan yang ada misalnya Puskesmas, sehingga dampak negatif seperti anemia, pertumbuhan terhambat, daya tahan tubuh menurun dapat segera diatasi.

Selain itu data tentang status kesehatan para pemulung dapat dijadikan acuan bagi pihak Puskesmas terkait dan Dinas Kesehatan Kota Makassar dalam rangka penyuluhan kesehatan kepada masyarakat, khususnya para pemulung yang ada di Kota Makassar. Sebagai bahan informasi kepada masyarakat tentang pentingnya menjaga kebersihan perorangan dan lingkungan sehingga bisa diterapkan PHBS (Perilaku Hidup Bersih dan Sehat).

\section{METODE}

\subsection{Pemeriksaan Penyakit}

\section{Kecacingan}

Metode yang digunakan untuk melakukan pemeriksaan Nematoda usus pada kuku tangan pemulung yaitu: Metode Sedimentasi untuk menentukan ada tidaknya telur atau larva nematoda usus dalam kuku pemulung yang diperiksa. 


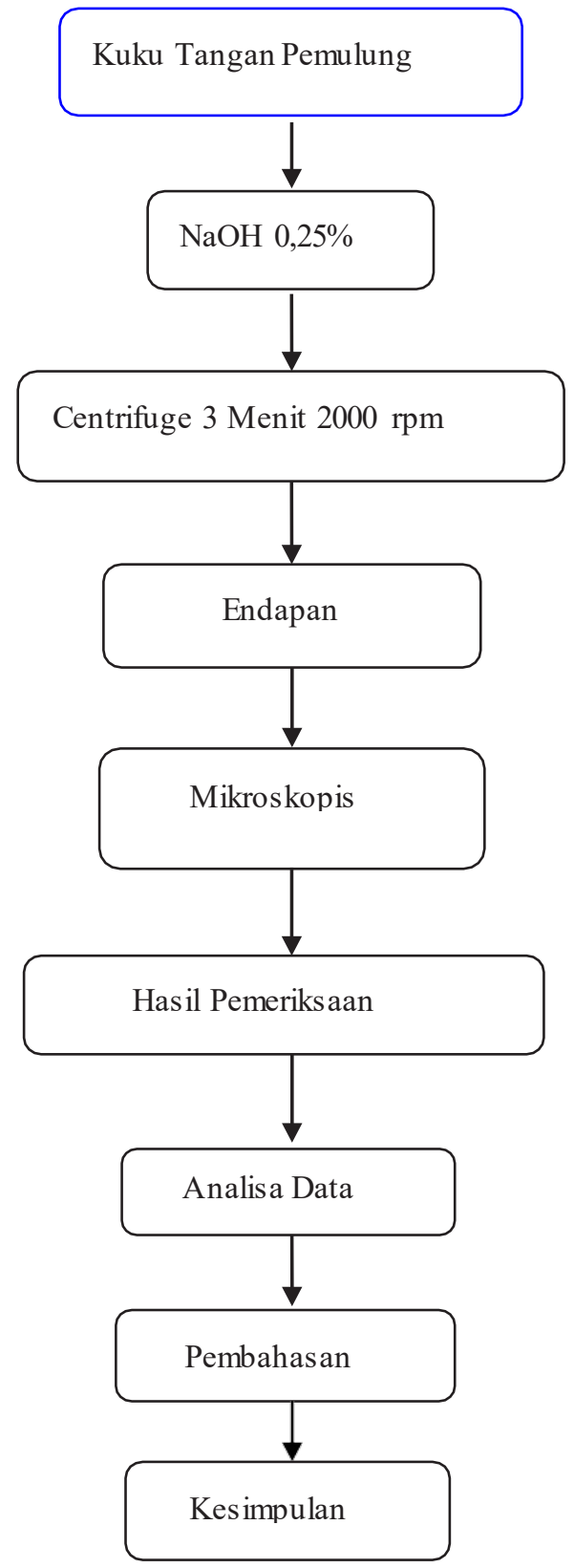

Gambar 1: Metode Pelaksanaan Pengabdian

Cara kerja metode Sedimentasi

: Pertama-tama dipotong kuku tangan pemulung, kemudian dimasukkan potongan kuku tangan tersebut ke dalam cawan petri yang mengand ung larutan $\mathrm{NaOH} 0,25 \%$. Larutan $\mathrm{NaOH}$ $0,25 \%$ yang berisi potongan kuku tangan dimasukkan ke dalam tabung sentrifuge. Diputar selama 3 menit pada kecepatan 2000 rpm, cairan supernatan dibuang. Sedimen diambil dengan menggunakan pipet, kemudian diletakkan pada objek glass dan ditutup dengan deck glass. Sedimen tersebut kemudian diperiksa di bawah mikroskop dengan pembesaran lensa objektif $10 \mathrm{X}$ dan 40X (Jangkung, 2002).

1. Penyuluhan Penyakit Kecacingan dan Pembagian Obat Cacing

Setelah melakukan pemeriksaan penyakit kecacingan, selanjutnya diberikan penyuluhan kesehatan kepada para pemulung. Materi penyuluhan yang diberikan terkait cara pencegahan dan penularan penyakit kecacingan, serta penyuluhan mengenai Perilaku Hidup Bersih dan Sehat (PHBS). Pada kegiatan ini juga dilakukan pembagian obat cacing kepada pemulung secara gratis.

2. Waktu dan Tempat Kegiatan

Pengambilan sampel kuku tangan pemulung untuk pemeriksaan penyakit kecacingan dan penyuluhan kesehatan serta pembagian obat cacing dilaksanakan pada tanggal 10-11 
Agustus 2020 di Tempat

Pemprosesan Akhir (TPA)

Sampah di Kelurahan Bangkala

Kecamatan Manggala Kota

Makassar.

3. HASIL

DAN

\section{PEMBAHASAN}

Pelaksanaan kegiatan pemeriksaan dan penyuluhan serta pembagian obat cacing diikuti oleh para pemulung di Kelurahan Bangkala Kecamatan Manggala Kota Makassar tepatnya di Tempat Pembuangan Akhir (TPA) Antang.

Tabel 1. Hasil Pemeriksaan dengan Metode Sedimentasi

\begin{tabular}{|c|c|c|}
\hline No & $\begin{array}{c}\text { KODE } \\
\text { SAMPEL }\end{array}$ & $\begin{array}{c}\text { HASIL } \\
\text { PEMERIKSAAN }\end{array}$ \\
\hline 1 & 1 & Negatif (-) \\
\hline 2 & 2 & Negatif (-) \\
\hline 3 & 3 & Negatif (-) \\
\hline 4 & 4 & Negatif (-) \\
\hline 5 & 5 & Negatif (-) \\
\hline 6 & 6 & Negatif (-) \\
\hline 7 & 7 & Negatif (-) \\
\hline 8 & 8 & Negatif (-) \\
\hline 9 & 9 & Negatif (-) \\
\hline 10 & 10 & Negatif (-) \\
\hline 11 & 11 & Negatif (-) \\
\hline 12 & 12 & Negatif (-) \\
\hline 13 & 13 & Negatif (-) \\
\hline 14 & 14 & Negatif (-) \\
\hline
\end{tabular}

\begin{tabular}{|c|c|c|}
\hline 15 & 15 & Negatif (-) \\
\hline 16 & 16 & Negatif (-) \\
\hline 17 & 17 & Negatif (-) \\
\hline 18 & 18 & Positif $(+)$ \\
\hline 19 & 19 & Negatif (-) \\
\hline 20 & 20 & Negatif (-) \\
\hline 21 & 21 & Negatif (-) \\
\hline 22 & 22 & Negatif (-) \\
\hline 23 & 23 & Negatif (-) \\
\hline 24 & 24 & Negatif (-) \\
\hline 25 & 25 & Negatif (-) \\
\hline 26 & 26 & Positif $(+)$ \\
\hline 27 & 27 & Negatif (-) \\
\hline 28 & 28 & Negatif (-) \\
\hline 29 & 29 & Negatif (-) \\
\hline 30 & 30 & Negatif (-) \\
\hline 31 & 31 & Negatif (-) \\
\hline 32 & 32 & Negatif (-) \\
\hline 33 & 33 & Negatif (-) \\
\hline 34 & 34 & Positif $(+)$ \\
\hline 35 & 35 & Negatif (-) \\
\hline 36 & 36 & Negatif (-) \\
\hline 37 & 37 & Negatif (-) \\
\hline 38 & 38 & Negatif (-) \\
\hline 39 & 39 & Negatif (-) \\
\hline 40 & 40 & Negatif (-) \\
\hline 41 & 41 & Negatif (-) \\
\hline 42 & 42 & Negatif (-) \\
\hline 43 & 43 & Negatif (-) \\
\hline 44 & 44 & Negatif (-) \\
\hline 45 & 45 & Positif $(+)$ \\
\hline 46 & 46 & Negatif (-) \\
\hline 47 & 47 & Negatif (-) \\
\hline 48 & 48 & Negatif (-) \\
\hline 49 & 49 & Negatif (-) \\
\hline 50 & 50 & Negatif (-) \\
\hline
\end{tabular}

Sumber : Data Primer, 2020 

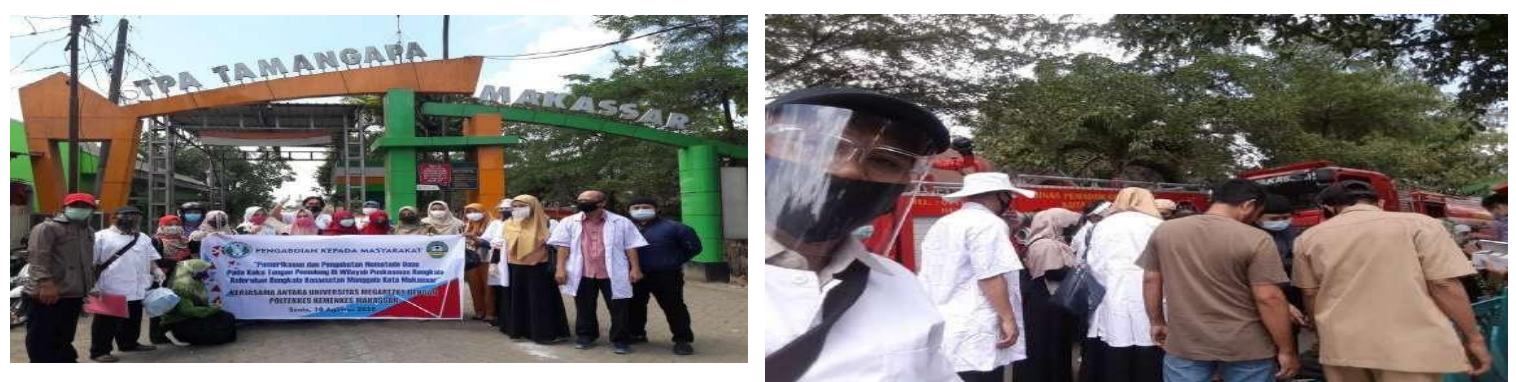

Gambar 2. Lokasi Pelaksanaan Pengabdian Gambar 3. Pengambilan Sampel kuku

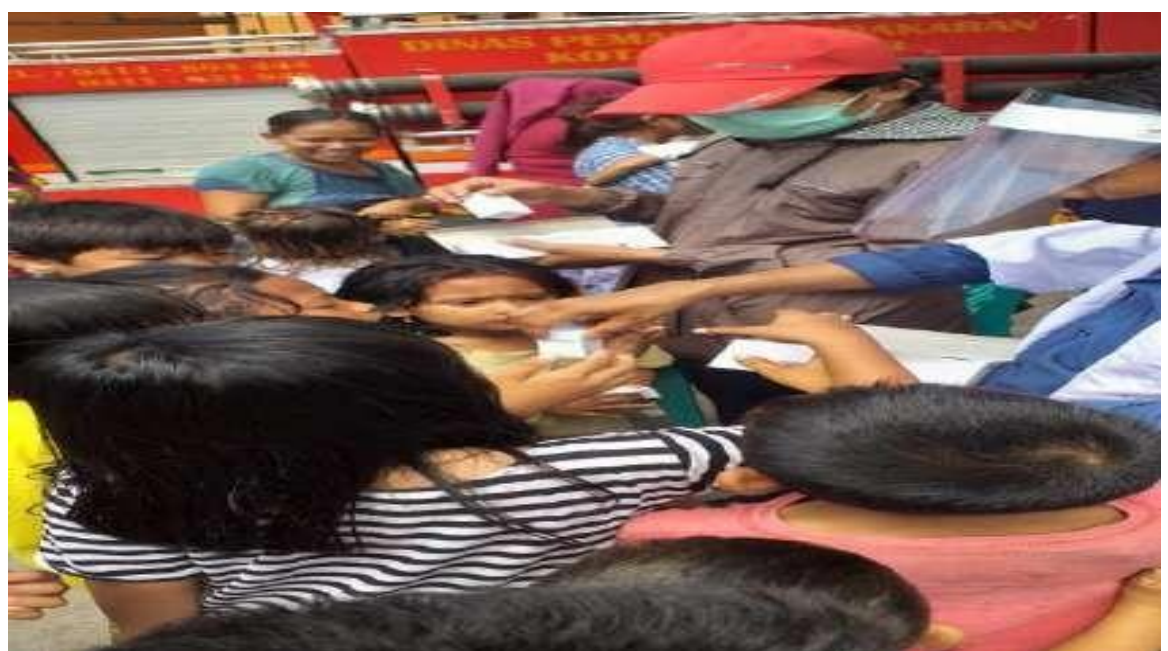

Gambar 4. Penyuluhan dan Pembagian Obat Cacing

\section{SIMPULAN}

Pemeriksaan penyakit kecacingan dan penyuluhan serta pembagian obat cacing kepada para pemulung di Kelurahan Bangkala Kecamatan Manggala Kota Makassar telah dilaksanakan dengan baik.

\section{DAFTAR PUSTAKA}

Anonim, 2009. Gambar Nematoda Usus

(http://www.images.geogle.co.i

d)
Etjang I, 2003. Mikrobiologi dan Parasitology untuk Akademi Keperawatan, PT. Citra Aditya Bakti

Gandahusada S, Ilahude. D.H, Pribadi, 2000. Parasitology Kedokteran, Jakarta Fakultas Kedokteran Universitas Indonesia, EdisiKetiga.

Garcia LS, Bruckner DA, 1996. Diagnostik Parasitology Kedokteran, Jakarta EGC. 
Ginting SA, 2003. Hubungan Antara

Status Sosial Ekonomi dengan

Kejadian

Kecacingan pada Anak Sekolah

Dasar Sumatera Utara.

http://www.Library.usu.ac.id/

modules, php

Hasnawati, 2005. Identifikasi Telur

Nematoda Usus pada Tanah

Halaman dan Sekitar Sekolah

SDN 97 Desa Sanrangeng

Kecamatan Dua Boccoe

Kabupaten Bone. Makassar

Ideham B, Pusarawati S, 2004. Buku

Penuntun Praktis Parasitologi

Kedokteran. Jakarta EGC

Onggowaluyo JS, 2000. Parasitologi

Medik Helmintologi. Jakarta

EGC
Rasmaliah, 2001. Ascaris dan Upay

Penanggulangannya.

(http:/library.usu.ac.id/module

s.php)

Syarif.S, 1993.Ilmu Tanah Pertanian, Bandung, Pustaka Buana

Sekartini R, 2004. Pengetahuan Sikap dan Perilaku Ibu yang Memiliki Anak Usia SD tentang Penyakit Cacingan di Kelurahan Pisangan BARU. Jaktim. (http:/www.artiket.com)

Sotejo, Kartasapoetra AG, 2006. Pengantar Ilmu Tanah. Jakarta, RinekaCipta Soedarto, 2008. Parasitologi Klinik, Surabaya : Airlangga University Press. 